\title{
EFFECTS OF LOSARTAN ON RENAL AND CARDIOVASCULAR OUTCOMES IN PATIENTS WITH TYPE 2 DIABETES AND NEPHROPATHY
}

\author{
Barry M. Brenner, M.D., Mark E. Cooper, M.D., Ph.D., Dick de Zeeuw, M.D., Ph.D., William F. Keane, M.D., \\ William E. Mitch, M.D., Hans-Henrik Parving, M.D., Giuseppe Remuzzi, M.D., Steven M. Snapinn, Ph.D., \\ Zhonxin Zhang, Ph.D., and Shahnaz Shahinfar, M.D., for the RENAAL Study InVestigators*
}

\begin{abstract}
Background Diabetic nephropathy is the leading cause of end-stage renal disease. Interruption of the renin-angiotensin system slows the progression of renal disease in patients with type 1 diabetes, but similar data are not available for patients with type 2, the most common form of diabetes. We assessed the role of the angiotensin-II-receptor antagonist losartan in patients with type 2 diabetes and nephropathy.
\end{abstract}

Methods A total of 1513 patients were enrolled in this randomized, double-blind study comparing losar$\tan$ (50 to $100 \mathrm{mg}$ once daily) with placebo, both taken in addition to conventional antihypertensive treatment (calcium-channel antagonists, diuretics, alpha-blockers, beta-blockers, and centrally acting agents), for a mean of 3.4 years. The primary outcome was the composite of a doubling of the base-line serum creatinine concentration, end-stage renal disease, or death. Secondary end points included a composite of morbidity and mortality from cardiovascular causes, proteinuria, and the rate of progression of renal disease.

Results A total of 327 patients in the losartan group reached the primary end point, as compared with 359 in the placebo group (risk reduction, 16 percent; $P=0.02$ ). Losartan reduced the incidence of a doubling of the serum creatinine concentration (risk reduction, 25 percent; $\mathrm{P}=0.006$ ) and end-stage renal disease (risk reduction, 28 percent; $P=0.002$ ) but had no effect on the rate of death. The benefit exceeded that attributable to changes in blood pressure. The composite of morbidity and mortality from cardiovascular causes was similar in the two groups, although the rate of first hospitalization for heart failure was significantly lower with losartan (risk reduction, 32 percent; $P=0.005)$. The level of proteinuria declined by 35 percent with losartan $(P<0.001$ for the comparison with placebo).

Conclusions Losartan conferred significant renal benefits in patients with type 2 diabetes and nephropathy, and it was generally well tolerated. (N Engl J Med 2001;345:861-9.)

Copyright (c) 2001 Massachusetts Medical Society.

I NTERRUPTION of the renin-angiotensin system with angiotensin-I-converting enzyme inhibitors slows the progression of renal disease both in patients with type 1 diabetes and in nondiabetic patients who have overt nephropathy. ${ }^{1-3}$ However, postponing end-stage renal disease in patients with type 2 diabetes, the leading cause of chronic renal failure in many countries, remains an elusive goal. We undertook a study in patients with type 2 diabetes and nephropathy in order to determine whether the angiotensin-II-receptor antagonist losartan, alone or in combination with conventional antihypertensive therapy, would increase the time to a doubling of the serum creatinine concentration, the onset of endstage renal disease, or death. In addition, we assessed the effects of losartan and placebo on the following secondary end points: a composite of morbidity and mortality from cardiovascular causes, proteinuria, and the rate of progression of renal disease.

\section{METHODS}

\section{Study Design}

The Reduction of Endpoints in NIDDM with the Angiotensin II Antagonist Losartan Study was an investigator-initiated, multinational, double-blind, randomized, placebo-controlled study designed to evaluate the renoprotective effects of losartan in 1513 patients with type 2 diabetes and nephropathy. The study design has been described previously. ${ }^{4}$ In brief, 250 centers in 28 countries in Asia, Europe, Central America, South America, and North America participated. The study protocol was approved by the institutional review board of each center, and all patients gave written informed consent. The study was overseen by steering and safety committees, each of which contained one nonvoting member who was an employee of the sponsoring pharmaceutical company. The steering committee oversaw the study design, the conduct of the trial, and the management and analysis of the data. A writing subcommittee of the steering committee prepared this report. An independent end-points committee whose members were unaware of the patients' treatment assignments reviewed the data to determine which patients had reached the end points.

We planned to complete the study 3.5 years after the last patient underwent randomization, which would have resulted in a mean follow-up time of 4.5 years. However, the study was discontinued early (February 10, 2001) by a unanimous vote of the steering committee, whose members were unaware of the treatment assignments. Their decision was based on new evidence suggesting that angiotensin-I-converting enzyme inhibitors, which were excluded by design from the study, may be effective in reducing the incidence of cardiovascular events in patients with renal impairment, includ-

From the Renal Division, Brigham and Women's Hospital, Boston (B.M.B.); the Department of Medicine, University of Melbourne, Melbourne, Victoria, Australia (M.E.C.); the Department of Clinical Pharmacology, University of Groningen, Groningen, the Netherlands (D.Z.); the Department of Medicine, Hennepin County Medical Center, Minneapolis (W.F.K.); the Renal Division, Emory University, Atlanta (W.E.M.); Steno Diabetes Center, Gentofte, Denmark (H.-H.P.); Laboratori Negri Bergamo, Istituto di Ricerche Farmacologiche Mario Negri, Bergamo, Italy (G.R.); and Merck Research Laboratories, Blue Bell, Pa. (S.M.S., Z.Z., S.S.). Address reprint requests to Dr. Brenner at the Renal Division, Brigham and Women's Hospital, 75 Francis St., Boston, MA 02115, or at bbrenner@partners.org.

*The investigators who participated in the RENAAL (Reduction of Endpoints in NIDDM with the Angiotensin II Antagonist Losartan) Study are listed in the Appendix. 
ing those with diabetes. ${ }^{5}$ Therefore, the results reported here represent a mean follow-up time of 3.4 years (range, 2.3 to 4.6 ).

\section{Patients}

The study involved male and female patients, ranging in age from 31 to 70 years, who had received diagnoses of type 2 diabetes and nephropathy. Nephropathy was defined by the presence on two occasions of a ratio of urinary albumin (measured in milligrams per liter) to urinary creatinine (measured in grams per liter) from a first morning specimen of at least 300 (or a rate of urinary protein excretion of at least $0.5 \mathrm{~g}$ per day) and serum creatinine values between 1.3 and $3.0 \mathrm{mg}$ per deciliter (115 and $265 \mu \mathrm{mol}$ per liter), with a lower limit of $1.5 \mathrm{mg}$ per deciliter (133 $\mu \mathrm{mol}$ per liter) for male patients weighing more than $60 \mathrm{~kg}$. Patients were excluded if they had received a diagnosis of type 1 diabetes or nondiabetic renal disease, including renal-artery stenosis. We also excluded patients who had had a myocardial infarction or had undergone coronary-artery bypass grafting within the previous month, who had had a cerebrovascular accident or had undergone percutaneous transluminal coronary angioplasty within the previous six months, who had had a transient ischemic attack within the previous year, or who had any history of heart failure before enrollment. ${ }^{4}$

\section{Treatment}

During the six-week screening phase, patients with hypertension continued to receive their standard antihypertensive therapy. If they had been taking angiotensin-I-converting enzyme inhibitors or angiotensin-II-receptor antagonists, however, these medications were discontinued and replaced by alternative open-label medications (diuretics, calcium-channel antagonists, alpha- or betablockers, centrally acting agents, or some combination of these types of medication). Patients were stratified according to their base-line level of proteinuria (a urinary albumin-to-creatinine ratio $<2000$ or $\geqslant 2000$ ) and randomly assigned to receive either losar$\tan (50 \mathrm{mg})$ or placebo once daily, along with conventional antihypertensive therapy. After four weeks, the dose of losartan or placebo was increased to $100 \mathrm{mg}$ or the placebo equivalent once daily if the trough blood pressure with the patient sitting was above the target level of a systolic blood pressure of less than $140 \mathrm{~mm} \mathrm{Hg}$ and a diastolic blood pressure of less than $90 \mathrm{~mm} \mathrm{Hg}$. After an additional eight weeks, antihypertensive agents of the types described above (but not angiotensin-I-converting enzyme inhibitors or angiotensin-II-receptor antagonists) were added or their doses increased to achieve the target blood pressure.

Throughout the study, patients received the standard of care for the treatment of diabetes, including measurements of glycosylated hemoglobin and fasting serum glucose concentrations. Visits were scheduled every three months, or more often if necessary, to monitor the blood pressure and laboratory measurements and to assess whether adverse events had occurred or end points had been reached. Patients who discontinued the study drugs early had follow-up visits every three months until the end of the study; at these visits, the primary and secondary end points reached were recorded, the blood pressure was measured, and laboratory measurements were performed. Those who could not return for clinic visits or a family member was contacted by telephone to determine whether they had reached the end points of the initiation of dialysis, renal transplantation, or death.

\section{Outcome Measures}

The primary efficacy measure was the time to the first event of the composite end point of a doubling of the serum creatinine concentration, end-stage renal disease, or death. The doubling of the serum creatinine concentration was defined as the first serum creatinine value that was twice the base-line value, as confirmed by a second serum creatinine value obtained at least four weeks after the initial doubling. End-stage renal disease was defined by the need for long-term dialysis or renal transplantation. The prespecified secondary end point, morbidity and mortality from cardiovascular causes, was a composite of myocardial infarction, stroke, first hospitalization for heart failure or unstable angina, coronary or peripheral revascularization, or death from cardiovascular causes. Analyses of the components of both the primary and secondary composite end points were also prespecified. Other secondary end points included the progression of renal disease ${ }^{6}$ and changes in the level of proteinuria.

\section{Statistical Analysis}

Analyses of the primary and secondary end points were performed according to the intention-to-treat principle; we included data from all randomized patients (with the exception of three patients who were lost to follow-up), from the time of randomization through the date of study termination. In a second, per-protocol analysis, we excluded patients who violated the criteria for inclusion and exclusion and censored patients' data 14 days after they permanently discontinued the study medication. A Cox regression model $^{7}$ that included the base-line level of proteinuria as a stratification factor and the geographic region as a covariate was used to determine the hazard ratio for the primary end point and its 95 percent confidence interval. The risk reduction was calculated as 100 percent $\times(1-$ hazard ratio $)$. In analyses of nonfatal end points, data for the patients who had died were considered to have been censored. Event curves are based on Kaplan-Meier analysis. ${ }^{8}$ We examined the effect of differences between the groups in the control of blood pressure by adding the mean arterial pressure during treatment as a time-dependent covariate in the Cox model and comparing the effect of losartan estimated by this model with that estimated by the primary analysis.

The analyses of the progression of renal disease and changes in the level of proteinuria were based on an on-treatment approach. For the analysis of the progression of renal disease, we compared the slopes of the reciprocal of the serum creatinine concentration ${ }^{6}$ of the two treatment groups using a linear random-effects model. Changes in the level of proteinuria in the two groups were compared by means of a mixed-effects model ${ }^{9}$ whose terms included the treatment at each point and the base-line level of proteinuria.

Because one interim analysis used a stopping boundary that was based on an alpha spending function of the O'Brien-Fleming type, ${ }^{10}$ a critical $\mathrm{P}$ value of 0.048 was required for the primary hypothesis. For other outcomes, a P value of less than 0.05 was considered to indicate statistical significance. All statistical tests were two-sided.

\section{RESULTS}

A total of 1513 patients were randomly assigned to receive losartan or placebo once daily, along with conventional antihypertensive therapy as needed but excluding angiotensin-I-converting enzyme inhibitors and angiotensin-II-receptor antagonists. The daily dose of losartan ranged from 50 to $100 \mathrm{mg}$, with 71 percent of the patients receiving $100 \mathrm{mg}$. The base-line characteristics were similar in the two groups (Table 1). More patients discontinued the study treatment in the placebo group ( 53.5 percent) than in the losartan group (46.5 percent). Adverse clinical events resulted in discontinuation in 17.2 percent of the patients in the losartan group, as compared with 21.7 percent of those in the placebo group. Increased serum concentrations of creatinine or potassium led to the discontinuation of the study medication in $\mathbf{1 . 5}$ percent and 1.1 percent, respectively, of the patients in the losartan group, as compared with 1.2 percent and 0.5 percent of the patients in the placebo group. A total of 7.5 percent of the patients in the losartan 
Table 1. Base-Line Characteristics of the Patients.*

\begin{tabular}{|c|c|c|}
\hline ChaRACteRISTIC & $\begin{array}{l}\text { LOSARTAN } \\
\text { GrouP } \\
(\mathrm{N}=751)\end{array}$ & $\begin{array}{c}\text { PLACEBo } \\
\text { GROUP } \\
(\mathrm{N}=762)\end{array}$ \\
\hline Age - yr & $60 \pm 7$ & $60 \pm 7$ \\
\hline \multicolumn{3}{|l|}{ Sex - no. (\%) } \\
\hline Male & $462(61.5)$ & $494(64.8)$ \\
\hline Female & $289(38.5)$ & $268(35.2)$ \\
\hline \multicolumn{3}{|l|}{ Race or ethnic group - no. (\%) } \\
\hline Asian & $117(15.6)$ & $135(17.7)$ \\
\hline Black & $125(16.6)$ & $105(13.8)$ \\
\hline White & $358(47.7)$ & $378(49.6)$ \\
\hline Hispanic & $140(18.6)$ & $136(17.8)$ \\
\hline Other & $11(1.5)$ & $8(1.0)$ \\
\hline Body-mass index $\dagger$ & $30 \pm 6$ & $29 \pm 6$ \\
\hline \multicolumn{3}{|l|}{ Blood pressure $-\mathrm{mm} \mathrm{Hg}$} \\
\hline Systolic & $152 \pm 19$ & $153 \pm 20$ \\
\hline Diastolic & $82 \pm 10$ & $82 \pm 11$ \\
\hline Mean arterial & $105.5 \pm 10.9$ & $106.0 \pm 11.6$ \\
\hline Pulse $\$$ & $69.4 \pm 17.4$ & $70.8 \pm 18.1$ \\
\hline \multicolumn{3}{|l|}{ Medical history — no. (\%) } \\
\hline Use of antihypertensive drugs & $693(92.3)$ & $721(94.6)$ \\
\hline Angina pectoris & $65(8.7)$ & $75(9.8)$ \\
\hline Myocardial infarction & $75(10.0)$ & $94(12.3)$ \\
\hline Coronary revascularization procedure & $1(0.1)$ & $1(0.1)$ \\
\hline Stroke & 0 & $1(0.1)$ \\
\hline Lipid disorder & $234(31.2)$ & $271(35.6)$ \\
\hline Amputation & $65(8.7)$ & $69(9.1)$ \\
\hline Neuropathy & $375(49.9)$ & $379(49.7)$ \\
\hline Retinopathy & $494(65.8)$ & $470(61.7)$ \\
\hline Current smoking & $147(19.6)$ & $130(17.1)$ \\
\hline \multicolumn{3}{|l|}{ Laboratory variables } \\
\hline Median urinary albumin:creatinine ratio & 1237 & 1261 \\
\hline & $1.9 \pm 0.5$ & $1.9 \pm 0.5$ \\
\hline \multicolumn{3}{|l|}{ Serum cholesterol $-\mathrm{mg} / \mathrm{dl} \|$} \\
\hline Total & $227 \pm 56$ & $229 \pm 55$ \\
\hline Low-density lipoprotein & $142 \pm 47$ & $142 \pm 45$ \\
\hline High-density lipoprotein & $45 \pm 16$ & $45 \pm 15$ \\
\hline Serum triglycerides $-\mathrm{mg} / \mathrm{dl}^{* *}$ & $213 \pm 180$ & $225 \pm 200$ \\
\hline Hemoglobin $-\mathrm{g} / \mathrm{dl}+\dagger$ & $12.5 \pm 1.9$ & $12.5 \pm 1.8$ \\
\hline Glycosylated hemoglobin - \% & $8.5 \pm 1.7$ & $8.4 \pm 1.6$ \\
\hline
\end{tabular}

*Plus-minus values are means $\pm \mathrm{SD}$. The differences between the treatment groups were not statistically significant.

†Body-mass index is the weight in kilograms divided by the square of the height in meters.

$\ddagger$ The mean arterial pressure was calculated as diastolic arterial pressure + (systolic arterial pressure - diastolic arterial pressure $) \div 3$.

$\$$ The pulse pressure was calculated as systolic arterial pressure - diastolic arterial pressure. ${ }^{11}$

ITo convert values to micromoles per liter, multiply by 88.4 .

$\|$ To convert values to millimoles per liter, multiply by 0.02586 .

**To convert values to millimoles per liter, multiply by 0.01129

$\dagger †$ To convert values to millimoles per liter, multiply by 0.6206 .

group and 7.8 percent of those in the placebo group withdrew their consent. We were able to determine the status of all patients (except for three patients in the losartan group who could not be contacted) with respect to dialysis, transplantation, and death.

\section{Blood Pressure}

At base line, 93.5 percent of the patients (92.3 percent in the losartan group and 94.6 percent in the placebo group) were receiving antihypertensive therapy. An additional 3 percent of the patients had hypertension but were not receiving antihypertensive therapy. The trough blood pressure declined progressively during the course of the study. The trough blood pressure at base line averaged $152 / 82 \mathrm{~mm} \mathrm{Hg}$ in the losartan group and $153 / 82 \mathrm{~mm} \mathrm{Hg}$ in the placebo group; the mean arterial pressure was 105.5 $\mathrm{mm} \mathrm{Hg}$ in the losartan group and $106.0 \mathrm{~mm} \mathrm{Hg}$ in the placebo group $(\mathrm{P}=0.38)$; and the pulse pressure was $69.4 \mathrm{~mm} \mathrm{Hg}$ in the losartan group and 70.8 $\mathrm{mm} \mathrm{Hg}$ in the placebo group $(\mathrm{P}=0.13)$. At one year, the values averaged $146 / 78 \mathrm{~mm} \mathrm{Hg}$ in the losartan group and $150 / 80 \mathrm{~mm} \mathrm{Hg}$ in the placebo group (mean arterial pressure, $100.9 \mathrm{~mm} \mathrm{Hg}$ and 103.1 $\mathrm{mm} \mathrm{Hg}$, respectively $[\mathrm{P}<0.001]$; pulse pressure, 67.8 $\mathrm{mm} \mathrm{Hg}$ and $69.8 \mathrm{~mm} \mathrm{Hg}$, respectively $[\mathrm{P}=0.05]$ ); at two years, the values were $143 / 77 \mathrm{~mm} \mathrm{Hg}$ and $144 / 77 \mathrm{~mm} \mathrm{Hg}$, respectively (mean arterial pressure, $99.1 \mathrm{~mm} \mathrm{Hg}$ and $99.7 \mathrm{~mm} \mathrm{Hg}$, respectively $[\mathrm{P}=$ 0.38 ]; pulse pressure, $66.2 \mathrm{~mm} \mathrm{Hg}$ and $67.1 \mathrm{~mm} \mathrm{Hg}$, respectively $[\mathrm{P}=0.37])$; and at the end of the study they were $140 / 74 \mathrm{~mm} \mathrm{Hg}$ and $142 / 74 \mathrm{~mm} \mathrm{Hg}$, respectively (mean arterial pressure, $95.9 \mathrm{~mm} \mathrm{Hg}$ and $96.8 \mathrm{~mm} \mathrm{Hg}$, respectively $[\mathrm{P}=0.59]$; pulse pressure, $66.7 \mathrm{~mm} \mathrm{Hg}$ and $67.4 \mathrm{~mm} \mathrm{Hg}$, respectively $[\mathrm{P}=$ $0.77])$. The various classes of conventional antihypertensive drugs that were used before and during the study are listed in Table 2.

\section{Primary Outcomes}

According to the intention-to-treat analysis, the primary composite end point of a doubling of the serum creatinine concentration, end-stage renal disease, or death was reached in 327 patients in the losartan group (43.5 percent), as compared with 359 in the placebo group (47.1 percent) (Fig. 1A). Treatment with losartan resulted in a 16 percent reduction in the risk of the primary composite end point $(\mathrm{P}=$ 0.02 ) (Table 3 ). The decrease in risk remained essentially unchanged (15 percent) after adjustment for blood pressure $(\mathrm{P}=0.03)$. Furthermore, according to the per-protocol analysis, among the patients who continued to receive their assigned study treatment, losartan conferred a 22 percent reduction in the risk of the primary composite end point $(\mathrm{P}=0.008)$.

The intention-to-treat analyses of the individual components of the primary composite end point are also shown in Table 3 . The risk of a doubling of the serum creatinine concentration was 25 percent lower in the losartan group than in the placebo group $(\mathrm{P}=0.006)$ (Fig. $1 \mathrm{~B})$. Losartan also reduced the risk of end-stage renal disease by 28 percent $(\mathrm{P}=0.002)$ (Fig. IC). Approximately 20 percent of the patients died, but there was no significant difference in mortality between the two groups $(\mathrm{P}=0.88)$. The risk of the combined end point of end-stage renal disease or death was 20 percent lower in the losartan group 
Table 2. Use of Conventional Antihypertensive Medications at Base Line AND DURING STUDY TREATMENT.

\begin{tabular}{|c|c|c|c|c|}
\hline \multirow[t]{2}{*}{ Class of Medication } & \multicolumn{2}{|c|}{ At BASE LINE } & \multicolumn{2}{|c|}{ During Study Treatment } \\
\hline & $\begin{array}{c}\text { LOSARTAN } \\
\text { GROUP } \\
(\mathrm{N}=751)\end{array}$ & $\begin{array}{c}\text { PLACEBO } \\
\text { GROUP } \\
(\mathrm{N}=762)\end{array}$ & $\begin{array}{c}\text { LOSARTAN } \\
\text { GROUP } \\
(\mathrm{N}=751)\end{array}$ & $\begin{array}{c}\text { PLACEBO } \\
\text { GROUP } \\
(\mathrm{N}=762)\end{array}$ \\
\hline & \multicolumn{4}{|c|}{ number (percent) } \\
\hline $\begin{array}{l}\text { Calcium-channel antagonist } \\
\text { Dihydropyridine }\end{array}$ & $\begin{array}{l}532(70.8) \\
406(54.1)\end{array}$ & $\begin{array}{l}546(71.6) \\
411(53.9)\end{array}$ & $\begin{array}{l}585(77.9) \\
456(60.7)\end{array}$ & $\begin{array}{l}618(81.1) \\
487(63.9)\end{array}$ \\
\hline Diuretic & $442(58.9)$ & $436(57.2)$ & $629(83.8)$ & $640(84.0)$ \\
\hline Alpha-blocker & $180(24.0)$ & $184(24.1)$ & $302(40.2)$ & $348(45.7)$ \\
\hline Beta-blocker & $137(18.2)$ & $140(18.4)$ & $256(34.1)$ & $280(36.7)$ \\
\hline Centrally acting agent & $80(10.7)$ & $84(11.0)$ & $135(18.0)$ & $165(21.7)$ \\
\hline $\begin{array}{l}\text { Angiotensin-I-converting enzyme inhib- } \\
\text { itor or angiotensin II antagonist }\end{array}$ & $400(53.3)$ & $376(49.3)$ & \multicolumn{2}{|c|}{ Excluded, per protocol } \\
\hline
\end{tabular}

than in the placebo group $(\mathrm{P}=0.01)$ (Fig. ID and Table 3 ). The reductions in the risk of end-stage renal disease and of end-stage renal disease or death changed little after correction for blood pressure (26 percent, $\mathrm{P}=0.007$, and 19 percent, $\mathrm{P}=0.02$, respectively).

\section{Secondary Outcomes}

There was no significant difference between the losartan group and the placebo group in the composite end point of morbidity and mortality from cardiovascular causes. Approximately one third of the patients had a fatal or nonfatal cardiovascular event (247 in the losartan group [32.9 percent] and 268 in the placebo group [ 35.2 percent]; risk reduction, 10 percent; $\mathrm{P}=0.26$ ). There were no significant differences in the rates of most of the cardiovascular end points; the exception was the first hospitalization with heart failure (89 patients in the losartan group [11.9 percent], as compared with 127 in the placebo group [16.7 percent]), for which the risk was reduced by 32 percent $(\mathrm{P}=0.005)$ (Fig. 2$)$. There was a difference between the number of myocardial infarctions in the losartan group ( 50 patients [6.7 percent]) and the number in the placebo group (68 patients [8.9 percent]; risk reduction, 28 percent), but this difference was not statistically significant $(\mathrm{P}=0.08)$.

Losartan also led to an average reduction in the level of proteinuria (the urinary albumin-to-creatinine ratio) of 35 percent, whereas in the patients in the placebo group, the urinary albumin-to-creatinine ratio tended to increase $(\mathrm{P}<0.001$ for the overall treatment effect) (Fig. 3). Losartan reduced the rate of decline in renal function, as assessed by the reciprocal of the serum creatinine concentration, by 18 percent (median slope, $-0.056 \mathrm{dl}$ per milligram per year in the losartan group, as compared with $-0.069 \mathrm{dl}$ per milligram per year in the placebo group; $\mathrm{P}=0.01$ ). Likewise, losartan was associated with a 15.2 percent reduction in the estimated decline in the glomerular filtration rate (median rate of decline, $4.4 \mathrm{ml}$ per minute per $1.73 \mathrm{~m}^{2}$ of body-surface area per year in the losartan group, as compared with $5.2 \mathrm{ml}$ per minute per $1.73 \mathrm{~m}^{2}$ per year in the placebo group; $\mathrm{P}=$ $0.01) .12,13$ These reductions in the rate of decline are far smaller than those reported for captopril as compared with placebo in patients with type 1 diabetes nearly a decade ago. ${ }^{1}$

\section{DISCUSSION}

Our study establishes that losartan, along with conventional antihypertensive treatment as needed, confers strong renal protection in patients with type 2 diabetes and nephropathy. The risk of the primary end point, a composite of a doubling of the serum creatinine concentration, end-stage renal disease, or death from any cause, was reduced by 16 percent with losartan. The primary benefit appeared to be the effect on the renal components of this composite end point. In particular, the risk of end-stage renal disease was reduced by 28 percent with losartan during an average follow-up of 3.4 years. Extrapolating from the observed data, we estimate that this reduction corresponds to an average delay of two years in the need for dialysis or transplantation. The risk of a doubling of the serum creatinine concentration was also reduced by 25 percent with losartan. The difference between the slopes of the reciprocals of the serum creatinine values and the lower level of proteinuria provide further evidence of global renal protection with losartan.

There was a small, time-averaged difference in the trough blood pressure between the losartan group 

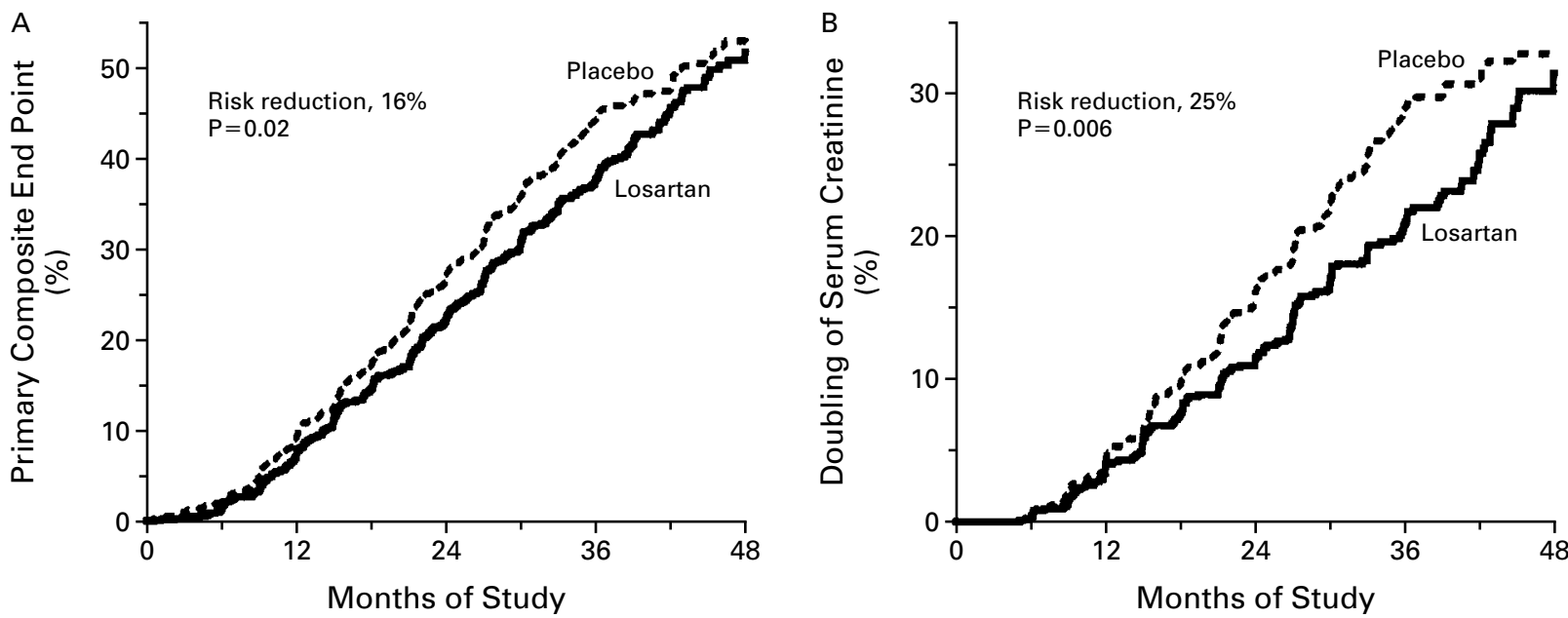

No. AT RISK

$\begin{array}{lllll}\text { Placebo } 762 & 689 & 554 & 295 & 36 \\ \text { Losartan } 751 & 692 & 583 & 329 & 52\end{array}$

$\begin{array}{lllll}762 & 689 & 554 & 295 & 36 \\ 751 & 692 & 583 & 329 & 52\end{array}$
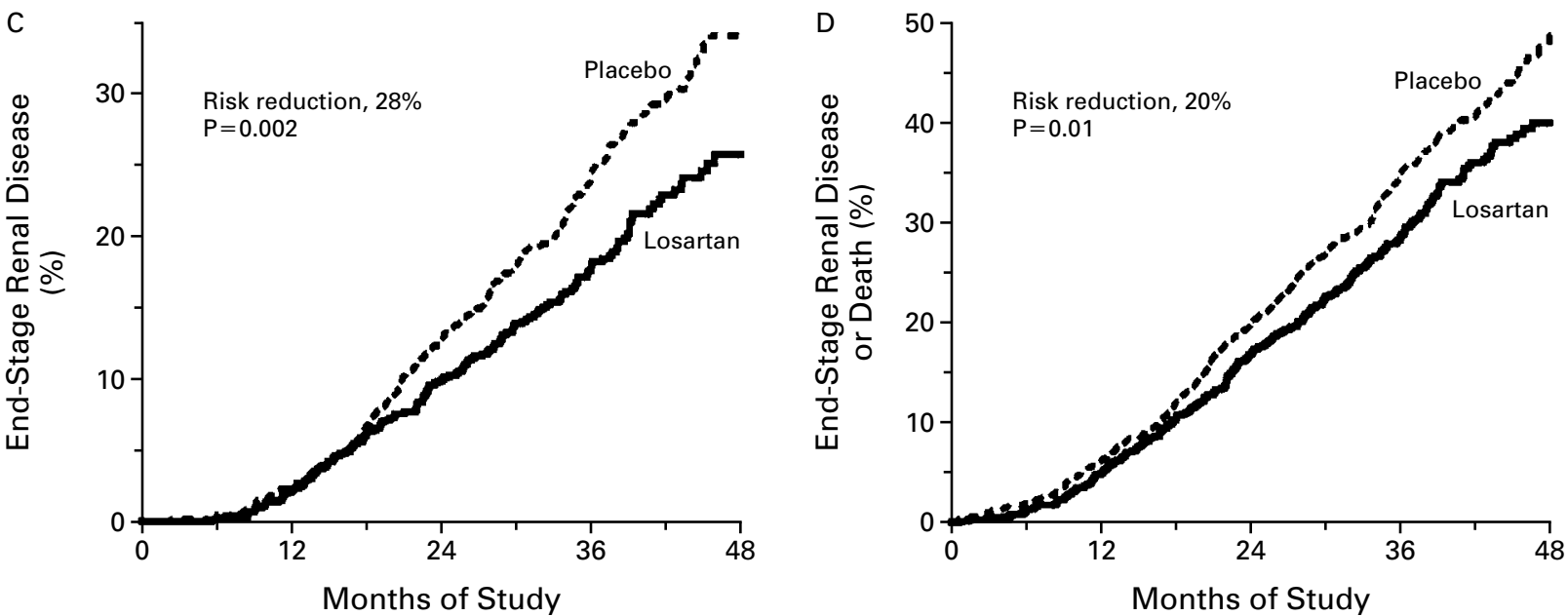

No. AT RISK

$\begin{array}{lllll}\text { Placebo } 762 & 715 & 610 & 347 & 42 \\ \text { Losartan } 751 & 714 & 625 & 375 & 69\end{array}$

69

$\begin{array}{lllll}762 & 715 & 610 & 347 & 42 \\ 751 & 714 & 625 & 375 & 69\end{array}$

Figure 1. Kaplan-Meier Curves of the Percentage of Patients with the Primary Composite End Point (Panel A) and Its Individual Components, a Doubling of the Serum Creatinine Concentration (Panel B), End-Stage Renal Disease (Panel C), and the Combined End Point of End-Stage Renal Disease or Death (Panel D).

The mean follow-up time was 3.4 years (42 months).

and the placebo group. We cannot exclude the possibility that this small difference had a beneficial effect on the renal outcomes. However, statistical analysis that corrected for these small differences confirmed that the renal protection conferred by losartan exceeded that attributable to any small differences in blood pressure. This study extends our knowledge of the efficacy of antihypertensive therapy in patients with type 2 diabetes and nephropathy. Previous studies involving angiotensin-I-converting enzyme inhibitors have demonstrated beneficial effects on proteinuria but have not demonstrated the superiority of blockade of the renin-angiotensin system in slowing the progression to end-stage renal disease over nonblockade forms of therapy. ${ }^{14-20}$ Indeed, studies of the effects of angiotensin-I-converting enzyme inhibitors 
Table 3. Incidence of the Primary Composite End Point and Its Components.*

\begin{tabular}{|c|c|c|c|c|c|c|}
\hline \multirow[t]{2}{*}{ End PoInt } & \multicolumn{2}{|c|}{$\begin{array}{l}\text { LOSARTAN GROUP } \\
(N=751)\end{array}$} & \multicolumn{2}{|c|}{$\begin{array}{l}\text { Placebo Group } \\
(N=762)\end{array}$} & \multirow[t]{2}{*}{ P Value } & $\begin{array}{c}\text { RISK } \\
\text { REDUCTION }\end{array}$ \\
\hline & no. (\%) & $\begin{array}{c}\text { no./100 } \\
\text { patient-yr }\end{array}$ & no. $(\%)$ & $\begin{array}{c}\text { no./100 } \\
\text { patient-yr }\end{array}$ & & $\%(95 \% \mathrm{Cl})$ \\
\hline Primary composite end point $\dagger$ & $327(43.5)$ & 15.9 & $359(47.1)$ & 18.1 & 0.02 & $16(2$ to 28$)$ \\
\hline $\begin{array}{l}\text { Doubling of serum creatinine } \\
\text { concentration }\end{array}$ & $162(21.6)$ & 7.9 & $198(26.0)$ & 10.0 & 0.006 & $25(8$ to 39$)$ \\
\hline End-stage renal disease & $147(19.6)$ & 6.8 & $194(25.5)$ & 9.1 & 0.002 & $28(11$ to 42$)$ \\
\hline Death & $158(21.0)$ & 6.8 & $155(20.3)$ & 6.6 & 0.88 & $-2(-27$ to 19$)$ \\
\hline End-stage renal disease or death & $255(34.0)$ & 11.7 & $300(39.4)$ & 14.1 & 0.01 & $20(5$ to 32$)$ \\
\hline $\begin{array}{l}\text { Doubling of serum creatinine } \\
\text { concentration and end-stage } \\
\text { renal disease }\end{array}$ & $226(30.1)$ & 11.0 & $263(34.5)$ & 13.2 & 0.01 & $21(5$ to 34$)$ \\
\hline
\end{tabular}

*In end-point trials, there is often a difference between the risk reduction as determined on the basis of the Cox regression model and the risk reduction as determined on the basis of the crude rates of events. The difference results in part from the fact that the Cox regression model accounts for the time at risk - i.e., the longer average follow-up in the losartan group than in the placebo group. To address this aspect of the difference, we present the numbers of events per 100 patient-years of follow-up. In addition, the Cox model accounts for the base-line level of proteinuria (which was a stratification factor) and the geographic region, as prespecified in the data analysis plan. CI denotes confidence interval.

†The primary end point was a composite of a doubling of the serum creatinine concentration, end-stage renal disease, or death.

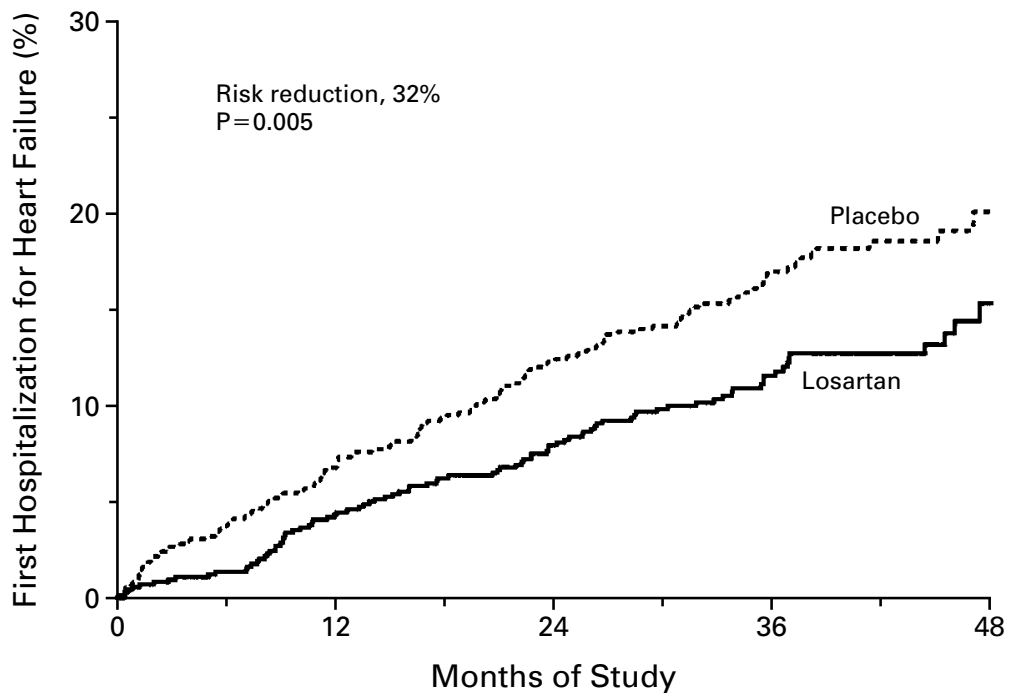

No. AT RISK

$\begin{array}{llllll}\text { Placebo } & 762 & 685 & 616 & 375 & 53 \\ \text { Losartan } & 751 & 701 & 637 & 388 & 74\end{array}$

Figure 2. Kaplan-Meier Curves of the Percentage of Patients with a First Hospitalization for Heart Failure in the Losartan and Placebo Groups.

Subsequent hospitalizations for heart failure were not assessed. There were 88 patients $(44$ in each group) who had preexisting heart failure at the time of randomization. When these patients were excluded from the analysis of this component, there remained a significant difference in the rate of first hospitalization for heart failure between the two treatment groups. The mean follow-up time was 3.4 years (42 months). 


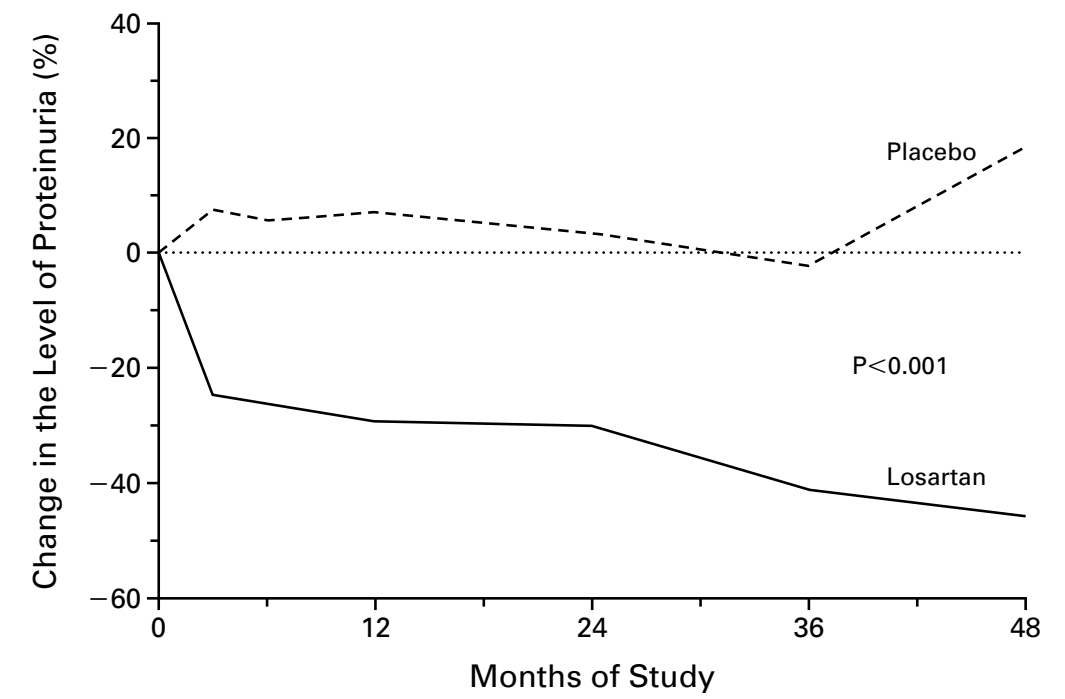

No. AT RISK

$\begin{array}{llllll}\text { Placebo } & 762 & 632 & 529 & 390 & 130 \\ \text { Losartan } & 751 & 661 & 558 & 438 & 167\end{array}$

Figure 3. Median Changes from Base Line in the Level of Proteinuria.

Proteinuria was measured as the urinary albumin-to-creatinine ratio in a first morning specimen. The mean follow-up time was 3.4 years.

on the progression of renal disease and end-stage renal failure have yielded conflicting results. ${ }^{14,15,20-24}$ Therefore, in the absence of a direct comparison between angiotensin-I-converting enzyme inhibitors and angiotensin II antagonists, any extrapolation from the results obtained with different classes of drugs is speculative at best.

The benefits of losartan were observed among our patients, many of whom were already receiving other therapies, such as aspirin, beta-blockers, and lipidlowering agents, as part of sound medical practice. Similarly, simultaneous therapy with calcium-channel antagonists did not detract from the beneficial effects of losartan, despite the recent controversy regarding the role of calcium-channel antagonists in the protection of the kidneys and the heart. ${ }^{25-27}$ In this regard, it should be noted that in related studies in patients with type 1 and type 2 diabetes, ${ }^{1,28,29}$ the benefits of captopril or irbesartan were not tested in the presence of concurrent calcium-channel-antagonist therapy. Furthermore, calcium-channel antagonists have been shown to augment the production of angiotensin II, ${ }^{30}$ a response that may be counteracted by concomitant angiotensin-II-receptor blockade.

There was no significant difference between the losartan group and the placebo group in the composite secondary end point of morbidity and mortality from cardiovascular causes. This similarity of in- cidence may have resulted in part from the relatively small sample and the strict criteria for enrollment that excluded patients at high risk for cardiovascular events including heart failure. We did find a significant difference in favor of losartan with regard to the rate of a first hospitalization for heart failure, a component of this secondary composite end point. This finding in patients without clinical heart failure at base line accords well with findings from the Studies of Left Ventricular Dysfunction Prevention study. ${ }^{31}$ That study, however, did not include patients with impaired renal function. The Heart Outcomes Prevention Evaluation (HOPE) Study ${ }^{32}$ and its substudy of patients with diabetes, MICRO-HOPE,${ }^{20}$ showed benefits of angiotensin-I-converting enzyme inhibition in terms of the signs and symptoms of heart failure but failed to show significant differences in hospitalizations for heart failure. Furthermore, the evaluation of a subgroup of the HOPE population with renal insufficiency ${ }^{5}$ did not show a significant effect on this outcome. Our findings suggest that angiotensin II blockade in patients with renal disease decreases the risk of overt heart failure resulting in hospitalization.

In this population, losartan (plus conventional antihypertensive therapy) demonstrated excellent tolerability, similar to that of placebo (plus conventional antihypertensive therapy), as evidenced by the similar numbers of patients in the two groups in whom 
the study treatment was discontinued because of adverse events. The addition of losartan to a conventional antihypertensive treatment regimen did not increase the incidence of adverse events.

End-stage renal disease continues to be a worldwide public health concern. Recent estimates by the National Institutes of Health indicate that diabetes represents the single largest cause of end-stage renal disease, accounting for approximately 40 percent of all cases in the United States between 1994 and $1998 .{ }^{33}$ Furthermore, the incidence of end-stage renal disease in patients with type 2 diabetes is rising sharply in many regions of the world and is expected to double by 2010 . The annual costs associated with end-stage renal disease in the United States reached $\$ 12$ billion in 1998 and are expected to surpass $\$ 28$ billion by $2010 .^{34}$ Preventing or delaying the progression of diabetic nephropathy is therefore an essential management goal. We believe our findings go a long way toward achieving this goal and may also have an important economic effect.

In summary, losartan led to significant improvement in renal outcomes that was beyond that attributable to blood-pressure control in patients with type 2 diabetes and nephropathy.

Supported by Merck and Company.

Dr. Brenner has served as a consultant to Merck, Bayer, Bristol-Myers Squibb, Aventis, AstraZeneca, Glaxo, and King. He has received research grants from Merck, Bayer, Bristol-Myers Squibb, and Novartis. He has been a member of speakers' bureaus sponsored by Merck, AstraZeneca, Bristol-Myers Squibb, and Novartis.

Dr. Cooper has served as a consultant to Pfizer, Sanofi, and Alteon. He has received research grants from AstraZeneca, Bristol-Myers Squibb, Merck, and Servier. He has been a member of speakers' bureaus sponsored by AstraZeneca and Solvay.

Dr. de Zeeuw has served as a consultant to Boehringer Ingelheim, Dade Behring, Merck Sharp \& Dohme, Pfizer, Takeda, and Yamanouchi. He has received research grants from Bristol-Myers Squibb, Boehringer Ingelheim, Dade Behring, Merck Sharp \& Dohme, Sanofi, and Yamanouchi. He has been a member of speakers' bureaus sponsored by Bristol-Myers Squibb, Dade Behring, and Merck Sharp \& Dohme.

Dr. Keane has served as a consultant to Bayer, Merck, AstraZeneca, and Monarch. He has received research grants from Bayer and Merck. He has been a member of speakers' bureaus sponsored by Bayer, Merck, AstraZeneca, and Monarch.

Dr. Mitch has served as a consultant to Merck and Biogen.

Dr. Parving has served as a consultant to Merck, Bristol-Myers Squibb, Sanofi, Pfizer, and BioStratum. He has received research grants from Merck, Bristol-Myers Squibb, Sanofi, and AstraZeneca. He has been a member of speakers' bureaus sponsored by Merck, Bristol-Myers Squibb, Sanofi, Pfizer, and AstraZeneca.

Dr. Remuzzi has received research grants from Aventis Pharma.

Drs. Snapinn, Zhang, and Shahinfar are employees of Merck and may own stock or hold stock options in Merck.

We are indebted to Roger L. Simpson, Denise R. Ramjit, Dr. Raymond P. Bain, and Dr. David J. van Dijk for their substantial contributions.

\section{APPENDIX}

The following persons participated in the Reduction of Endpoints in NIDDM with the Angiotensin II Antagonist Losartan Study: Independent Steering Committee: B.M. Brenner, M.E. Cooper, D. de Zeeuw, J.P. Grunfeld, W.F. Keane, K. Kurokawa, J. McGill, W.E. Mitch, H.-H. Parving, G. Remuzzi, A.B. Ribeiro, M. Schluchter; Independent Data Safety Monitoring Committee: C.E. Mogensen, M. Fifer, L. Fisher, P. Kowey, D. Schlon- dorff, G. Viberti, P. Whelton; Independent Endpoint Committee: S Haffner, J. Carrozza, D. Kolansky, L. Raij, D. Sica, R. Toto; Primary Investigators (the numbers in parentheses are the numbers of patients in each country): Argentina (17) - F. Inserra, L. Juncos; Austria (15) - C. Gurdet, J.R. Patsch, H. Toplak; Brazil (58) - S. Silveiro, V. Woronik, T. Zanella; Canada (1) - E. Burgess, T.C. Monchesky; Chile (26) - F. González; Costa Rica (33) - M. Vinoccour; Czech Republic (33) - P. Boucek, R. Chlup, J. Olsovsky, P. Sifalda; Denmark (16) - P. Christensen; France (12) - T. Hannedouche, P. Passa, M. Rodier; Germany (12) - B. Boehm, H.-D. Bundschu, U. Leonhardt; Hong Kong, China (92) - J. Chan, J. Critchley, K. Lam; Hungary (10) - S. Sonkodi; Israel (37) - D.J. van Dijk; Italy (26) - G. Piras, G. Remuzzi, F. Santeusanio; Japan (96) - R. Abe, Y. Ando, T. Fujita, T. Hanafusa, M. Haneda, T. Haneda, Y. Hashimoto, T. Ida, Y. Iino, S. Ishibashi, S. Ito, H. Kakuta, M. Kanazawa, T. Kanda, M. Kasuga, M. Kato, T. Koike, H. Kurahachi, H. Kuzuya, K. Matoba, D. Nagasaku, K. Ohshiro, K. Okada, S. Owada, H. Sakai, J. Seino, C. Shigemasa, T. Shoji, Y. Tsubakihara, N. Ujihara, N. Ura, T. Watanabe, I. Yamaji, Y. Yamasaki, M. Yoshinari, N. Yoshioka; Malaysia (2l) - C.T. Chua, Z Morad; Mexico (67) - R. Correa, J. Herrera; the Netherlands (7) - J.-E. Heeg, R. Gansevoort, P.L. Rensma; New Zealand (3) - R. Scott; Peru (42) - R. Zavala; Portugal (10) - B. Carvalho; Russia (26) - M. Shestakova, G. Zalevskaya; Singapore (11) - K.S. Wong; Slovak Republic (2) M. Pavlovic; Spain (67) - J.M. Bronsons, M.M. Campos Pastor, D. del Castillo-Caba, F. Diz-Lois, F. Escobar-Jiménez, M.T. Gonzalez-Alvarez, D. Lorenzo, A. Martínez-Castelao, J.M. Martínez García, A. Tejedor-Jorge, M. Valles-Prats; United Kingdom (56) - C. Fox, E. Hillhouse, M. MacLeod, M. MacMahon, J. Mclay, P. O'Hare, V. Patel, H. Tindall, J.P. Vora, J.U. Weaver; United States, including Puerto Rico (686) - S. Abramson, J.R. Allison III, J. Anderson, G. Appel, M. Avram, G. Bakris, Y. Barri, J. Beard, D. Bell, J. Benabe, R. Benedetti, W. Bennett, W.K. Bolton, J.P. Brennan, M. Broder, M. Cabezas-Mijuste, D. Calhoun, A. Carr, L. Chan, B. Chandler, Jr., G. Chao, D. Chapman, J. Chinn, J. Christensen, J. Chung, C. Clinkingbeard, G. Collins, C. Corder, D. Crittenden, P. Dandona, M. Davis, R. DeFronzo, V. DeQuattro, G. Dolson, J. Douglas, M. Doyle, M. EckertNorton, A. Edin, M. El Shahawy, D. Elson, J.G. Evans, G. Fain III, T. Ferguson, J. Fica, C. Fisher, D. Fitz-Patrick, D. Frid, R. Galagan, L. Gaudiani, J. Geohas, M. Goldberg, R. Goldberg, J. Gorkin, R. Goulah, R. Graf, M. Greenspan, A. Guasch, C. Guerin, N. Gupta, C.E. Guthrow, S. Haffner, J. Hamilton, L.L. Hamm, L. Hancock, J. Hawkins, K. Hershon, W. Herzog, J. Holtzman, J. Insel, G. Jilly, L. Jovanovic, L. Katz, G. Kaysen, G. Keightley III, D. Kereiakes, G. Kershaw, B. Kerzner, R. Khairi, C. Kilo, M. Kipnes, R. Kipperman, L.D. Knoll, W. Kraus, J. Lash, J. LeLevier, S. Lerman, F.M. Lester, B. Levine, R. Louard, K. Ma, R. Maddox, D. Mapel, S. Martin, R. Mayfield, J. McGill, J.F. McNeer, J. Miller, S. Miller, B. Miskin, M. Mohan, T. Mooney, B. Musa, P. Nachman, A. Nafziger, J. Nardandrea, Jr., M. Nunez, L. Olansky, P. Pagnozzi, J. Pappas, T. Parker, T. Patel, B. Phillipson, J. Pino, D. Pitts, P. Raskin, P. Reber, E. Reisin, J. Ringold, V. Roberts, D. Roh, J. Rosenstock, N. Rossi, E. Rubin, L. Rubin, D. Ruff, M. Salem, R. Santangelo, Y. Segal, K.S. Self, S. Sharma, J. Sloand, L.K. Smith, R. Solomon, C. Spellman, B. Spinowitz, D. Steward, W. Suki, S. Swan, A. Swislocki, M. Tonkon, R. Toto, N.D. Vaziri, S. Vicks, J. Villamizar, R. Vranian, T. Walden, F. Wei, M. Weinberg, M. Weir, C. Williamson, L. Wruble, W. Yeung, F. Ziel; Venezuela (31) - A. Perez, J. Weisinger; Coordinating Center, Merck Research Laboratories: Program Coordinators - R. Simpson, D. Ramjit, S. Thompson-Bell, B. McVan, D. Fong, R. Poston, G. Drucker, M. McFadden-Neyer, M. Hinz, C. Assang, D. Brown, S. Mereminsky, C. Curry, G. McPeters, B. Bertino, International Liaisons - J. Lorfing, B. Koslowski, C. Wagner, C. Arena; Statisticians - S. Snapinn, H Zhang, C. White, A. Carides, D. Snavely; Data Coordinators - D. Wolf, J. Sickel, C. Shanahan, K. Morgan, S. Plourde; Clinical Supply Coordinator - B. Vanslembrouck.

\section{REFERENCES}

1. Lewis EJ, Hunsicker LG, Bain RP, Rohde RD. The effect of angioten sin-converting-enzyme inhibition on diabetic nephropathy. N Engl J Med 1993;329:1456-62.

2. Maschio G, Alberti D, Janin G, et al. Effect of the angiotensin-converting-enzyme inhibitor benazepril on the progression of chronic renal insufficiency. N Engl J Med 1996;334:939-45.

3. Randomised placebo-controlled trial of effect of ramipril on decline in glomerular filtration rate and risk of terminal renal failure in proteinuric, non-diabetic nephropathy: the GISEN Group. Lancet 1997;349:1857-63. 4. Brenner BM, Cooper ME, de Zeeuw D, et al. The Losartan Renal Protection Study: rationale, study design and baseline characteristics of RENAAL (Reduction of Endpoints in NIDDM with the Angiotensin II Antagonist Losartan). J Renin Angiotensin Aldosterone Syst 2000;1(4): 328-35.

5. Mann JFE, Gerstein HC, Pogue J, Bosch J, Yusuf S. Renal insufficiency 
as a predictor of cardiovascular outcomes and the impact of ramipril: the HOPE randomized trial. Ann Intern Med 2001;134:629-36.

6. Mitch WE, Walser M, Buffington GA, Lemann J Jr. A simple method of estimating progression of chronic renal failure. Lancet 1976;2:1326-8. 7. Cox DR. Regression models and life-tables. J R Stat Soc [B] 1972;34: 187-220.

8. Kaplan EL, Meier P. Nonparametric estimation from incomplete observations. J Am Stat Assoc 1958;53:457-81.

9. The mixed procedure. In: SAS Institute. SAS/STAT software: changes and enhancements through release 6.12. Cary, N.C.: SAS Institute, 1977 573-701.

10. O'Brien PC, Fleming TR. A multiple testing procedure for clinical trials. Biometrics 1979;35:549-56.

11. Black HR, Kuller LH, O'Rourke MF, et al. The first report of the Systolic and Pulse Pressure (SYPP) working group. J Hypertens 1999;17: Suppl 5:S3-S14.

12. Levey AS, Bosch JP, Lewis JB, Greene T, Rogers N, Roth D. A more accurate method to estimate glomerular filtration rate from serum creatinine: a new prediction equation. Ann Intern Med 1999;130:461-70.

13. Levey AS, Greene T, Kusek JW, Beck GJ. A simplified equation to predict glomerular filtration rate from serum creatinine. J Am Soc Nephrol 2000;11:155A. abstract.

14. Walker WG, Hermann J, Anderson J, Zachary J, Russell RP. Blood pressure (BP) control slows decline of glomerular filtration rate (GFR) in hypertensive NIDDM patients. J Am Soc Nephrol 1992;3:339. abstract.

15. Lebovitz HE, Wiegmann TB, Cnaan A, et al. Renal protective effects of enalapril in hypertensive NIDDM: role of baseline albuminuria. Kidney Int Suppl 1994;45:S150-S155.

16. Bakris GL, Copley JB, Vicknair N, Sadler R, Leurgans S. Calcium channel blockers versus other antihypertensive therapies on progression of NIDDM associated nephropathy. Kidney Int 1996;50:1641-50.

17. Nielsen FS, Rossing P, Gall MA, Skott P, Smidt UM, Parving HH. Long-term effect of lisinopril and atenolol on kidney function in hypertensive NIDDM subjects with diabetic nephropathy. Diabetes 1997;46:11828 .

18. Fogari R, Zoppi A, Corradi L, et al. Long-term effects of ramipril and nitrendipine on albuminuria in hypertensive patients with type II diabetes and impaired renal function. J Hum Hypertens 1999;13:47-53.

19. Estacio RO, Jeffers BW, Gifford N, Schrier RW. Effect of blood pressure control on diabetic microvascular complications in patients with hypertension and type 2 diabetes. Diabetes Care 2000;23:Suppl 2:B54-B64. 20. Heart Outcomes Prevention Evaluation (HOPE) Study Investigators. Effects of ramipril on cardiovascular and microvascular outcomes in people with diabetes mellitus: results of the HOPE study and MICRO-HOPE substudy. Lancet 2000;355:253-9.

21. Ravid M, Savin H, Jutrin I, Bental T, Katz B, Lishner M. Long-term stabilizing effect of angiotensin-converting enzyme inhibition on plasma creatinine and on proteinuria in normotensive type II diabetic patients. Ann Intern Med 1993;118:577-81

22. Ahmad J, Siddiqui MA, Ahmad H. Effective postponement of diabetic nephropathy with enalapril in normotensive type 2 diabetic patients with microalbuminuria. Diabetes Care 1997;20:1576-81

23. Ruggenenti P, Perna A, Gherardi G, Benini R, Remuzzi G. Chronic proteinuric nephropathies: outcomes and response to treatment in a prospective cohort of 352 patients with different patterns of renal injury. Am J Kidney Dis 2000;35:1155-65.

24. Efficacy of atenolol and captopril in reducing risk of macrovascular and microvascular complications in type 2 diabetes. UKPDS 39: U.K. Prospective Diabetes Study Group. BMJ 1998;317:713-20.

25. Agodoa LY, Appel L, Bakris GL, et al. Effect of ramipril vs amlodipine on renal outcomes in hypertensive nephrosclerosis: a randomized controlled trial. JAMA 2001;285:2719-28.

26. Estacio RO, Jeffers BW, Hiatt WR, Biggerstaff SL, Gifford N, Schrier $\mathrm{RW}$. The effect of nisoldipine as compared with enalapril on cardiovascular outcomes in patients with non-insulin-dependent diabetes and hypertension. N Engl J Med 1998;338:645-52.

27. Tatti P, Pahor M, Byington RP, et al. Outcome results of the Fosinopril versus Amlodipine Cardiovascular Events Randomized Trial (FACET) in patients with hypertension and NIDDM. Diabetes Care 1998;21:597-603. 28. Lewis EJ, Hunsicker LG, Clarke WR, et al. Renoprotective effect of the angiotensin-receptor antagonist irbesartan in patients with nephropathy due to type 2 diabetes. N Engl J Med 2001;345:851-60.

29. Parving H-H, Lehnert H, Bröchner-Mortensen J, Gomis R, Andersen $S$, Arner P. The effect of irbesartan on the development of diabetic nephropathy in patients with type 2 diabetes. N Engl J Med 2001;345:870-8. 30. Bauer JH, Reams GP. Antihypertensive drugs. In: Brenner BM, ed. The kidney. 6th ed. Philadelphia: W.B. Saunders, 2000:2253-97.

31. The SOLVD Investigators. Effect of enalapril on mortality and the development of heart failure in asymptomatic patients with reduced left ventricular ejection fractions. N Engl J Med 1992;327:685-91.

32. The Heart Outcomes Prevention Evaluation Study Investigators. Effects of an angiotensin-converting-enzyme inhibitor, ramipril, on cardiovascular events in high-risk patients. N Engl J Med 2000;342:145-53.

33. National Institutes of Health. Excerpts from the United States Renal Data System's 2000 annual data report: atlas of end-stage renal disease in the United States: incidence and prevalence of ESRD. Am J Kidney Dis 2000;36:Suppl 2:S37-S54.

34. National Institutes of Health. Excerpts from the United States Renal Data System's 2000 annual data report: atlas of end-stage renal disease in the United States: economic costs of ESRD. Am J Kidney Dis 2000;36: Suppl 2:S163-S176.

Copyright (C) 2001 Massachusetts Medical Society. 